\title{
Rozwój jakości środowiskowej wyrobu z uwzględnieniem wpływu przepisów bezpieczeństwa na przykładzie zasilacza komputerowego
}

\author{
The Development of The Environmental Quality of Product \\ with Regard To Safety Regulations Based On The Example \\ Of a Computer Power Supply Unit
}

\begin{abstract}
$\mathrm{W}$ artykule omówiono jeden $\mathrm{z}$ aspektów przeprowadzonej przy pomocy metody LCA szerokiej oceny środowiskowej zasilacza komputerowego jako wyrobu elektrycznego. W ramach zagadnienia wykonano wiele badań wyrobu w ujęciu cyklu życia w celu określenia wywieranych przez wyrób presji środowiskowych, zidentyfikowania ich źródeł, a także określenia kluczowych zależności środowiskowych istotnych dla wyrobu.

W ramach niniejszego artykułu zbadano uwarunkowania legislacyjne wpływające na rozwój produktu i wynikające bezpośrednio z nich zmiany wprowadzone w budowie wyrobu. Wyniki tej analizy stanowią podstawę wyszczególnienia wariantów wyrobu i związku ich konstrukcji i parametrów z przepisami prawa, a także oceny wpływu środowiskowego wprowadzonych zmian. Scharakteryzowano także zmiany wynikające $\mathrm{z}$ drogi doskonalenia jakości produktu i dostosowania jego projektu do nowych wymagań użytkowych, które wyszczególniono w przedstawionych wariantach wyrobu. Przy pomocy badań scenariuszowych i metody oceny szkód środowiskowych Impact'2002+ porównano owe warianty oraz dokonano oceny wywieranego przez nie wpływu na środowisko. Zweryfikowano obrany kierunek rozwoju wyrobu w kontekście korzyści środowiskowych w całym cyklu życia.
\end{abstract}

Słowa kluczowe:

LCA, bezpieczeństwo, środowisko, urządzenia elektryczne
The article discusses one of the aspects of the computer power supply extensive environmental assessment as an electrical product, using the LCA method. Within the framework, a series of product tests in life cycle terms were performed, in order to determine the environmental pressures exerted by the product, identify their sources, as well as determine the key environmental relationships relevant to the product.

As part of this article, the legislative conditions affecting product development and the direct changes introduced in the construction of the product were examined. The results of this analysis are the basis for specifying the product variants and the relationship between their construction and parameters and legal provisions, as well as the environmental impact assessment of the changes introduced. The changes resulting from the way of improving product quality and adapting its design to the new usage requirements, which are detailed in the variants of the product, were also characterized. With the help of scenario studies and the Impact'2002+ environmental damage assessment method, these variants and their environmental impacts were compared. It was verified whether the chosen product development direction brings environmental benefits throughout the whole life cycle.

Key words:

LCA, safety, environment, electrical devices 


\section{Bibliografia}

Adamczyk, J., Nitkiewicz, T. (2007). Programowanie zrównoważonego rozwoju przedsiębiorstw. Warszawa: Polskie Wydawnictwo Ekonomiczne.

Angryk, R., Bandosz, M., Hoffman, R. M., Olejniczak, W. (2005). E-gospodarka. W: E. Kolbusz, W. Olejniczak, Z. Szyjewski (red.). Inżynieria systemówinformatycznych we-gospodarce. Warszawa: Polskie Wydawnictwo Ekonomiczne.

Chudorliński, J., Michalski, P. (2015). Wymagania kompatybilności elektromagnetycznej w elektroenergetycznej automatyce zabezpieczeniowej. Przegląd Elektrotechniczny, 91(11), 7-10.

Chwaleba, A., Płoszajski, G., Moeschke, B. (2008). Elektronika. Warszawa: WSiP.

Czarnecki, L. S. (2005). Moce $w$ obwodach elektrycznych z niesinusoidalnymi przebiegami prądów $i$ napięć. Warszawa: Oficyna Wydawnicza Politechniki Warszawskiej.

Dostatni, E., Karwasz, A. (2009). Systemy informatyczne wspomagające proekologiczne projektowanie. Zarządzanie Przedsiębiorstwem, 12(2), $13-22$.

Fryze, S. (1931). Moc rzeczywista, urojona i pozorna w obwodach elektrycznych o przebiegach odkształconych prądu i napięcia. Przegląd Elektrotechniczny, (7), 193-203.

Humbert, S., Schryver, A., Bengoa, X., Margni, M., Jolliet, O. (2012). Impact 2002+: User Guide. Lausanne: Swiss Federal Institute of Technology Lausanne (EPFL) in Switzerland. https://www.quantis-intl.com/pdf/IMPACT2002_UserGuide_for_vQ2.21.pdf (5.06.2019).

Hutyra, A. (1998). Dyrektywy dotycząceniskiego napięcia i kompatybilności elektromagnetycznej. Warszawa: Wydawnictwo Granit.

Intel (1997). ATX specification ver. 1.3 and ver. 2.0.1. - Technical review and documentation. https:/web.aub.edu.lb/pub/docs/ (5.06.2019).Jolliet, O., Margni, M., Charles, R., Humbert, S., Payet, J., Rebitzer, G., Rosenbaum, R. (2003). Impact 2002+: A New Life Cycle Impact Assessment Methodology. International Journal of Life Cycle Assessment, (8), 324-330.

Nowak, J., Kosobudzki, G. (2010). Moc obiektów elektroenergetycznych. Prace naukowe Instytutu Maszyn, Napędów i Pomiarów Elektrycz- nych Politechniki Wrocławskiej, 64(30), 479-492.

PN-EN 60335-1:2012. (2014). Elektryczny sprzęt do użytku domowego i podobnego — Bezpieczeństwo użytkowania - Część 1: Wymagania ogólne. Warszawa: Polski Komitet Normalizacyjny.

Polskie Centrum Badań i Certyfikacji S.A. (2015). Program Certyfikacji Wyrobów Elektrycznych - Certyfikacja na znak bezpieczeństwa „B” (DBW01-B). Warszawa: PCBC. http://www.pcbc.gov.pl/images/certyfikacja/wyroby/dokumenty/DBW-01-B.pdf (5.06.2019).

Rychwalski, M. (2010), Application of the SimaPro Program in Implementation of the Sustainable Development Concept. W: V. Modrák, T. Nitkiewicz (red.). The Role of Business in Achieving Sustainability Instruments and Strategies (t. 1, 140-154), Prešov: University of Košice.

Rychwalski, M., Wojnarowska, M. (2013). Modelowanie efektów zarządzania środowiskowego w przedsiębiorstwie. W: W. Adamczyk (red.), Działania ekologiczne w polityce produktowej przedsiębiorstw(143-153), Kraków: Wydawnictwo Naukowe Akapit.

Stański, K. (2016). Program certyfikacji wyrobów elektrycznych. Certyfikacja na wspólny znak towarowy gwarancyjny „B PCBC”. Warszawa: Polskie Centrum Badań i Certyfikacji S.A.

Weidema, B. P., Bauer, C., Hischier, R., Mutel, C., Nemecek, T., Reinhard, J., Vadenbo, C. O., Wernet, G. (2013). Ecoinvent Overview and methodology. Data quality guideline for the ecoinvent database version 3 - final. Ecoinvent report No. 1 (v3), St. Gallen: Swiss Centre for Life Cycle Inventories.

\section{Źródla internetowe}

http://www.neotec.pl (5.06.2019).

https://www.energystar.gov/ (5.06.2019).

Dyrektywa 2001/95/WE Parlamentu Europejskiego i Rady z 3.12.2001 r. w sprawie ogólnego bezpieczeństwa produktów (Dz.Urz. WE L11, s. 4 , ze zm.).

Dyrektywa 2002/96/WE Parlamentu Europejskiego i Rady z 27.01.2003 r. w sprawie zużytego sprzętu elektrotechnicznego i elektronicznego (WEEE) (Dz.Urz. WE L 37, s. 24, ze zm.).

Dyrektywa 2004/108/WE Parlamentu Europejskiego i Rady z 15.12.2004 r. w sprawie zbliżenia ustawodawstw państw członkowskich odnoszących się do kompatybilności elektromagnetycznej oraz uchylająca dyrektywę 89/336/EWG (Dz.Urz. UE L 390, s. 24).

Dyrektywa 2006/95/WE Parlamentu Europejskiego i Rady z 12.12.2006 r. w sprawie harmonizacji ustawodawstw państw członkowskich odnoszących się do sprzętu elektrycznego przewidzianego do stosowania w określonych granicach napięcia (Dz.Urz. UE L 374, s. 10).

Dyrektywa 2014/30/UE Parlamentu Europejskiego i Rady z 26.02.2014 r. w sprawie harmonizacji ustawodawstw państw członkowskich odnoszących się do kompatybilności elektromagnetycznej (Dz.Urz. UE L 96, s. 79, ze zm.).

Dyrektywa delegowana komisji (UE) 2015/863 z 31.03.2015 r. zmieniająca załącznik II do dyrektywy Parlamentu Europejskiego i Rady 2011/65/UE w odniesieniu do wykazu substancji objętych ograniczeniem (Dz.Urz. UE L 137, s. 10).

Dyrektywa Parlamentu Europejskiego i Rady 2012/19/UE z 4.07.2012 r. w sprawie zużytego sprzętu elektrycznego i elektronicznego (WEEE) (Dz.Urz. UE L 197, s. 38, ze zm.).

Dyrektywa Parlamentu Europejskiego i Rady 2014/35/UE z 26.02.2014 r. w sprawie harmonizacji ustawodawstw państw członkowskich odnoszących się do udostępniania na rynku sprzętu elektrycznego przewidzianego do stosowania w określonych granicach napięcia (Dz.Urz. UE L 96, s. 357).

Ustawa z 22.02.2019 r. o zmianie ustawy — Prawo ochrony środowiska (Dz. U. 2019 poz. 452)

Obwieszczenie Marszałka Sejmu Rzeczypospolitej Polskiej z 29.06.2018 r. w sprawie ogłoszenia jednolitego tekstu ustawy o zużytym sprzęcie elektrycznym i elektronicznym (Dz.U. 2018 poz. 1466) 